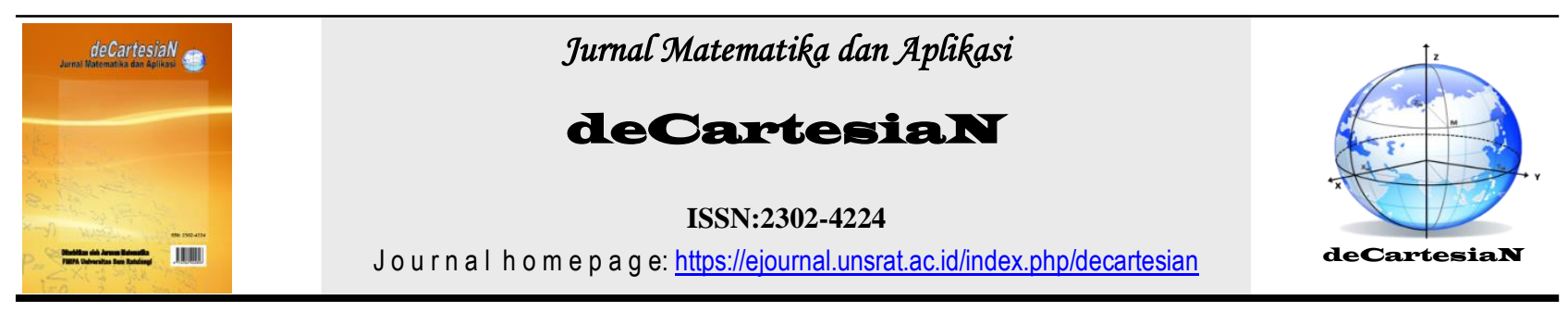

\title{
Application of Decision Support System Based On GUI to Determine The Best Mall In Manado City By Using ELECTRE Method
}

\author{
Kenedi Binowo', Altien J. Rindengan', Benny Pinontoan' ${ }^{*}$ \\ ${ }^{1}$ Mathematics Departement-Faculty of Mathematics and Natural Science-Sam Ratulangi University, Manado, Indonesia \\ ${ }^{*}$ Corresponding author : bpinonto@yahoo.com
}

\begin{abstract}
A B S T R A C T
Mall is a shopping center that has numerous functions, and the mall has become a place of human survival, therefore this research is done to choose the best mall in Manado city which is Jumbo, Mega Trade Center, Manado Town Square, Mega Mall, and Multimart. The ELECTRE method is one of the multi-criteria decisionmaking methods based on the concept of outranking by using pairwise comparisons of alternatives based on each appropriate criterion. The purpose of this research is to find out the best mall in Manado city based on ELECTRE method, and to find out the most important thing in designing GUI based application system. GUI is a decision support program in mathematics programs. From the research result using ELECTRE method can be known that the best mall in Manado city is Mega Mall, because from the best calculation result is $\mathrm{A}_{4}$ (Alternative 4 ), where if $\mathrm{E}_{\mathrm{kl}}=1$ indicates that alternative $\mathrm{A}_{\mathrm{k}}$ is the chosen alternative. The results of GUI-based applications it has been perform a result that the most important thing in the making is: There must be a place of input value, there should be an output display, and there should be execution buttons, and most importantly also that must create a coding in accordance with the programming language that can be read by mathematics programs.
\end{abstract}

\author{
ARTICLE INFO \\ Received \\ : February 25, 2018 \\ Received in revised form : March 8, 2018 \\ Available online $\quad$ : March 31, 2018
}

\author{
Keywords: \\ Mall, \\ ELECTRE Method, \\ Decision Support System \\ GUI Application
}

\section{INTRODUCTION}

In modern era economic growth has been increased because of great quantities of mall building in Indonesia particularly in Manado. One of many reasons that establish an economic growth in a city is the rise of mall construction. It indicates that a city which has a mall construction has a decent economics system. As a people in a big city, the people must know that a mall not merely for increasing an economic growth of the region but mall has several function. It will be eliminated a fatigue in the mind, as a refreshing place, place of travel, possibly will be survival place for human, even mall does not offer a basic needs but needs of entertainment and almost all the necessities of human life.

The Elimination And Choice Translation Reality (ELECTRE) method is one of the multi-criteria decision-making methods based on the concept of outranking by using pairwise comparisons of alternatives based on each appropriate criterion [1]. An example of the ELECTRE method used in decision making is used by Marlinda (2016) under the title "Decision Support System For Yogyakarta Tourism Place Using Elimination Et Choix Traduisant La Realita (Electre) Methods ". The reason why the author chose the method of ELECTRE? It has been elected by the researcher because the ELECTRE Method is capable of completing the recommendations of multi-criteria cases in determining the best mall selection in Manado, and the ELECTRE method also chosen by the researcher, because the solution is subsequently unique, long, accurate, and requires precision in every step of solution, this are the reason why the author to choose the method of ELECTRE in the appeal of other methods.

In this research, application that will be used is Graphical User Interface (GUI) application. GUI is a decision support program in Mathematics Laboratory (MATLAB), GUI application has many advantages in itself, including: GUI is suitable for science-oriented applications, in the M-File size GUI produced relatively small, the graphics capability is quite reliable and not absent compared to other programming languages.

\section{MALL}

Mall is a shopping centre that is the core of one or more large department store as the appeal of small retails and restaurants with a typology of buildings such as the store overlooking the main corridors of the mall which is the main element of the a shopping centre (mall), with function as circulation and as a space for this communal interactions between visitors and traders. The elements in the mall can be devided in three 
types, that's : Visitor, Goods, and Traders and Managers [2].

\section{MANADO CITY}

Manado is capital of the province North Sulawesi. Manado city is located in the Bay of Manado, and surrounded by mountainous areas. The city has a population of 408,354 at the 2010 Census, this made the Manado city as the second largest city on the island of Sulawesi after Makassar. The population of Manado city was estimated (based on January 2016) is 427,906 [3]. Religion is practised in Manado city is a Christian, Moeslim, Roman Catholicism, Hinduism, Buddhism and Confucianism. Based on the population census of 2010 year, the population of Christians 62,10 percent, Catholic 5,02 percent, while the Muslim 31,30 percent and rest is other religious. Currently the majority of population in Manado city comes from Minahasa tribe, because the territory of Manado is being on the ground/area of Minahasa.

\section{DECISION SUPPORT SYSTEM}

Decision support system is an interactive information system that provides information, modeling, and data manipulating. This system is used to assist in the decision making process in a situation that semi-structured and unstructured situations, where no one knows are uncertain how decisions should be made. Decision support systems are usually built to support the solution of a problem or to evaluate an opportunity. Decision support system more geared to supporting management in doing work which is analytic in a situation that is less structured and less obvious criteria. Decision support systems are not intended to automate the decision making, but provides an interactive device that enables decision makers to perform various analysis using available models [4].

\section{ELIMINATION AND CHOICE TRANSLATION REALITY (ELECTRE)}

According to [5], ELECTRE is one of methods multicriteria decision making based on concept of outranking by using paired comparison of alternatives based on according any criteria. ELECTRE methods used in conditions where the lesser alternative in accordance with criteria eliminated, and appropriate alternatives can be generated. In other words, ELECTRE is used for cases with many alternatives but only a few criteria that involved. An alternative is supposed to be dominated another alternative if one or more of message exceeds (in comparison with other alternatives of the criteria) and the same with the other criteria remaining [6]. The steps undertaken in completion of ELECTRE method as follows:

\subsection{Decision of Matrix Normalization}

In this procedure, each attribute is changed to value of compareable. Any normalization rij can be done with equation (1) [7].

$$
r_{i j}=\frac{x_{i j}}{\sqrt{\sum_{i=1}^{m} x_{i j}^{2}}}
$$

for $i=1,2,3, \ldots, \mathrm{m}$ and $j=1,2,3, \ldots, \mathrm{n}$ normalization is.

$$
\mathrm{R}=\left[\begin{array}{cccc}
r_{11} & r_{12} & \cdots & r_{1 n} \\
r_{21} & r_{22} & \cdots & r_{2 n} \\
\cdots & \cdots & \cdots & \vdots \\
r_{m 1} & r_{m 2} & \cdots & r_{m n}
\end{array}\right], \mathrm{R} \text { is a matrix that has }
$$

been normalized, where $m$ stated alternatives, $n$ stated criteria and $r_{i j}$ is a normalization of the measurement options from alternative to- $i$ in relation to criteria to- $j$.

\subsection{Weighting on matrix $V$}

After normalized, each column of matrix $\mathrm{R}$ multiplied by the weighting $\left(w_{j}\right)$ defined by the decision maker [7]. Thus, the wighted normalized matrix is.

$$
\begin{gathered}
V=W R \text { written in equations (2). } \\
\mathrm{WR}=\left[\begin{array}{cccc}
w_{1} r_{11} & w_{2} r_{12} & \cdots & w_{n} r_{1 n} \\
w_{1} r_{21} & w_{2} r_{22} & \cdots & w_{n} r_{2 n} \\
\cdots & \cdots & \cdots & \vdots \\
w_{1} r_{m 1} & w_{2} r_{m 2} & \cdots & w_{n} r_{m n}
\end{array}\right]=\mathrm{V} \\
=\left[\begin{array}{cccc}
v_{11} & v_{12} & \cdots & v_{1 n} \\
v_{21} & v_{22} & \cdots & v_{2 n} \\
\cdots & \cdots & \cdots & \vdots \\
v_{m 1} & v_{m 2} & \cdots & v_{m n}
\end{array}\right]
\end{gathered}
$$

\subsection{Determine Concordance and Discordance Index}

According to [6], for each pair of alternatives to $k$ and $l(k, l=1,2,3, \ldots, m)$ collected of the criteria $J$ divided into two subsets, that is concordance and discordance. When a criterion in one alternative includes concordance was:

$$
C_{k l}=\left\{j, V_{k j} \geq V_{i j}\right\}, \text { for } j=1,2,3, \ldots, n
$$

Instead, it is a subset of the complementary discordance, is:

$D_{k l}=\left\{j, V_{k j}<V_{i j}\right\}$, for $j=1,2,3, \ldots, n$

\subsection{Concordance and Discordance of Dominant Matrix}

1). Concordance

The dominant matrix concordance can be built with help threshold values, that's by comparing each value element matrix concordance (C) with threshold value [7].

$$
C_{k l} \geq \underline{c}
$$

Threshold value $c$ is:

$$
\underline{c}=\frac{\sum_{k=1}^{n} \sum_{l=1}^{n} C_{k l}}{m(m-1)}
$$

$f_{k l}=1$, if $C_{k l} \geq \underline{c}$ and $f_{k l}=0$, if $C_{k l}<\underline{c}$

2). Discordance

To build the dominant matrix discordance is also using help of threshold value $d$, is:

$$
\begin{gathered}
\underline{d}=\frac{\sum_{k=1}^{n} \sum_{l=1}^{n} d_{k l}}{m(m-1)} \\
g_{k l}=1, \text { If } d_{k l} \geq \underline{d} \text { and } g_{k l}=0, \text { if } d_{k l}<\underline{d}
\end{gathered}
$$

\subsection{Determine Aggregate Dominance Matrix}

The next stage is determining the aggregate dominance matrix as matrix E, which every element is multiplication between the elements of matrix $\mathrm{F}$ with elements of matrix $G$, calculation matrix $E$ using equation (12) [7]. (Matrix $\mathrm{E}$ is a term product between matrices $\mathrm{F}$ and $\mathrm{G}$ matrices selected by the inventor of the ELECTRE method).

$$
e_{k l}=f_{k l} * g_{k l}
$$

\subsection{Elimination of Less Favourable Alternative}

Matrix $\mathrm{E}$ gives the order of preference of any alternatives, that is when $e_{k l}=1$ then the alternative is $A_{k}$ better than $A_{l}$ consequently that rows in matrix $\mathrm{E}$ which has the fewest $e_{k l}=1$ can be eliminated. Thus 
the best alternative is dominating the other alternatives [6].

\section{RESEARCH METODOLOGY}

\subsection{Research Data}

The data used in this research is the primary data, obtained from the respondent through the questionnaire. In this research the data to use is alternative data and criteria. That following is of data to use in research. Including data alternative that is: $A_{1}=$ Jumbo, $A_{2}=$ MTC, $A_{3}=$ MANTOS, $\mathrm{A}_{4}=$ Mega Mall, and $\mathrm{A}_{5}=$ Multimart and data criteria is: $\mathrm{C} 1$ $=$ Comfort, $\mathrm{C}_{2}=$ Cleanllines, $\mathrm{C}_{3}=$ Location Layout, $\mathrm{C}_{4}=$ Hospitality, $\mathrm{C} 5=$ Beauty, C6 $=$ Prices Basic Communities, $\mathrm{C}_{7}=$ Main facility, C8 = Complementary Facility, C9 = Supporting Facility.

\subsection{Analysis Methods}

To analyze the best mall in Manado city, formerly do steps of analysis ELECTRE methods. Chart of analysis method that is presented in Figure 1.

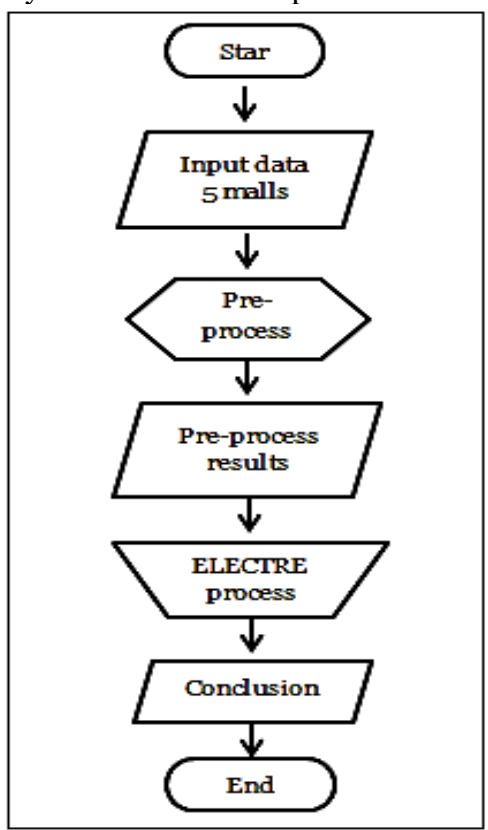

Figure 1.Chart Analysis Method

\subsection{Application System Design}

For the application system design that is presented through in dynamics diagram system development method (Figure 2). Dinamic System Development Method (DSDM) is a framework that implements information systems [8].

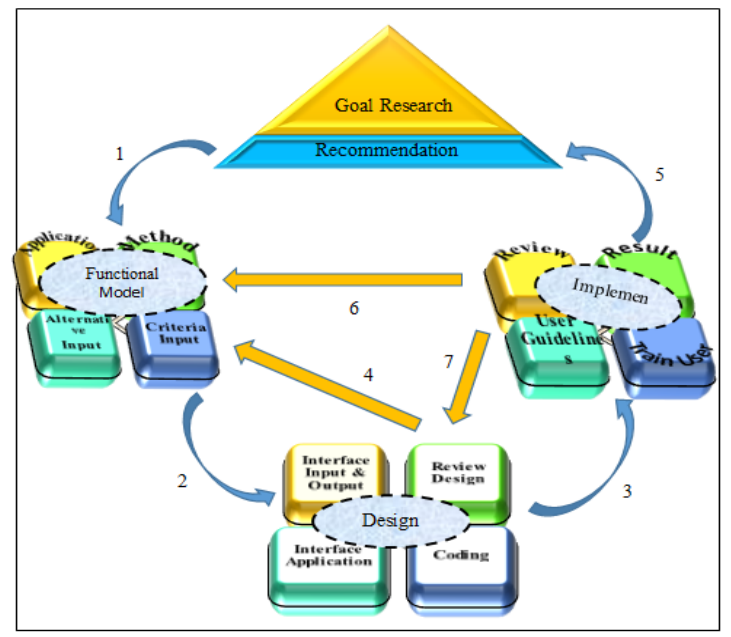

Figure 2. Chart Dinamic System Development Method

\section{RESULT AND DISCUSSION}

\subsection{Process Input Data}

Data that has been used as input that is 5 alternatives ( 5 malls in manado City) and 9 criteria (comfort, cleanliness, suitable location, hospitality, the beauty, the prices of basic commodities, the main facility, supporting facilities and complementary facilities). It criteria of inputing data is an indicator which is used for selection of the best mall recommendations in Manado. Input data in table 1 is a result of an assessment of 100 respondents.

Table 1. Process Input Data

\begin{tabular}{|c|c|c|c|c|c|}
\hline \multirow{2}{*}{$\begin{array}{l}\text { Cri- } \\
\text { teria }\end{array}$} & \multicolumn{5}{|c|}{ Alternative } \\
\hline & $\mathbf{A}_{1}$ & $\mathbf{A}_{2}$ & $\mathbf{A}_{3}$ & $\mathbf{A}_{4}$ & $\mathbf{A}_{5}$ \\
\hline C1 & $\begin{array}{l}\text { Quite } \\
\text { Comfort } \\
\text { able }\end{array}$ & $\begin{array}{l}\text { Quite } \\
\text { Comfort } \\
\text { able }\end{array}$ & $\begin{array}{c}\text { Comfort } \\
\text { able }\end{array}$ & $\begin{array}{l}\text { Comfo } \\
\text { rtable }\end{array}$ & $\begin{array}{l}\text { Comfo } \\
\text { rtable }\end{array}$ \\
\hline $\mathrm{C2}$ & $\begin{array}{l}\text { Quite } \\
\text { Clean }\end{array}$ & $\begin{array}{l}\text { Quite } \\
\text { Clean }\end{array}$ & Clean & Clean & Clean \\
\hline C3 & $\begin{array}{c}\text { Quite } \\
\text { Suitable } \\
\text { and } \\
\text { Strategic }\end{array}$ & $\begin{array}{c}\text { Quite } \\
\text { Suitable } \\
\text { and } \\
\text { Strategic }\end{array}$ & $\begin{array}{c}\text { Suitable } \\
\text { and } \\
\text { Strategic }\end{array}$ & $\begin{array}{c}\text { Suitab } \\
\text { le and } \\
\text { Strate } \\
\text { gic }\end{array}$ & $\begin{array}{c}\text { Suitab } \\
\text { le and } \\
\text { Strate } \\
\text { gic }\end{array}$ \\
\hline C4 & $\begin{array}{c}\text { Quite } \\
\text { Hospital } \\
\text { ity } \\
\end{array}$ & $\begin{array}{c}\text { Quite } \\
\text { Hospital } \\
\text { ity }\end{array}$ & $\begin{array}{c}\text { Hospital } \\
\text { ity }\end{array}$ & $\begin{array}{l}\text { Hospit } \\
\text { ality }\end{array}$ & $\begin{array}{l}\text { Hospit } \\
\text { ality }\end{array}$ \\
\hline $\mathrm{C}_{5}$ & $\begin{array}{l}\text { Quite } \\
\text { Beauty }\end{array}$ & $\begin{array}{l}\text { Quite } \\
\text { Beauty }\end{array}$ & Beauty & Beauty & $\begin{array}{l}\text { Quite } \\
\text { Beauty }\end{array}$ \\
\hline C6 & Cheap & Quite & $\begin{array}{l}\text { Expensi } \\
\text { ve }\end{array}$ & Quite & Quite \\
\hline $\mathbf{C}_{7}$ & $\begin{array}{c}\text { Quite } \\
\text { Complet } \\
\mathrm{e}\end{array}$ & $\begin{array}{c}\text { Quite } \\
\text { Complet } \\
\mathrm{e}\end{array}$ & $\begin{array}{c}\text { Complet } \\
\mathrm{e}\end{array}$ & $\begin{array}{l}\text { Compl } \\
\text { ete }\end{array}$ & $\begin{array}{c}\text { Quite } \\
\text { Compl } \\
\text { ete }\end{array}$ \\
\hline C8 & $\begin{array}{c}\text { Not } \\
\text { Complet } \\
\mathrm{e}\end{array}$ & $\begin{array}{c}\text { Quite } \\
\text { Complet } \\
\mathrm{e} \\
\end{array}$ & $\begin{array}{c}\text { Complet } \\
\mathrm{e}\end{array}$ & $\begin{array}{c}\text { Compl } \\
\text { ete }\end{array}$ & $\begin{array}{l}\text { Quite } \\
\text { Compl } \\
\text { ete }\end{array}$ \\
\hline C9 & $\begin{array}{c}\text { Quite } \\
\text { Complet } \\
\mathrm{e}\end{array}$ & $\begin{array}{c}\text { Quite } \\
\text { Complet } \\
\mathrm{e}\end{array}$ & $\begin{array}{c}\text { Complet } \\
\mathrm{e}\end{array}$ & $\begin{array}{c}\text { Compl } \\
\text { ete }\end{array}$ & $\begin{array}{l}\text { Quite } \\
\text { Compl } \\
\text { ete }\end{array}$ \\
\hline
\end{tabular}

\subsection{Pre-Process}

The stage of pre-process ELECTRE methods that is determine suitability rating on each criterion. Equal rating is determined based on results of interviews through a questionnaire that has been divided to respondent, which consists of: 
1. Comfortness in the Mall?

$$
\begin{aligned}
& 1=\text { Very Uncomfortable } \\
& 2=\text { Not Comfortable } \\
& 3=\text { Quite Comfortable } \\
& 4=\text { Comfortable } \\
& 5=\text { Very Comfortable }
\end{aligned}
$$

2. Cleanliness in the Mall?

$$
\begin{aligned}
& 1=\text { Not Clean } \\
& 2=\text { Less Clean } \\
& 3=\text { Quite Clean } \\
& 4=\text { Clean } \\
& 5=\text { Very Clean }
\end{aligned}
$$

3. Layout of the Mall location is suitable and strategic?

$$
1=\text { Not very Suitable and Strategic }
$$

$2=$ Not Suitable and Strategic

$3=$ Quite Suitable and Strategic

$4=$ Suitable and Strategic

$5=$ Very Suitable and Strategic

4. Hospitality of employees in the Mall? (it starts from security guard, kasier, and etc.)

$$
\begin{aligned}
& 1=\text { Not Very Hospitable } \\
& 2=\text { Not Hospitable } \\
& 3=\text { Quite Hospitable } \\
& 4=\text { Hospitable } \\
& 5=\text { Very Hospitable }
\end{aligned}
$$

5. Beautification of the Mall?

$$
1=\text { Not Beautiful }
$$

2= Beautiful Passable

3= Quite Beautiful

$4=$ Beautiful

$5=$ Very Beautiful

6. Prices of basic acommodities in Mall? (that's rice, Sugar, vegetables, fruits, meat/fish, cooking oil/ Soil \& Lpg, milk, eggs, Chili/Onions/ Tomato, etc, and other Flavorings)

$$
\begin{aligned}
& 1=\text { Very Cheap } \\
& 2=\text { Cheap } \\
& 3=\text { Quite } \\
& 4=\text { Expensive } \\
& 5=\text { Very Expensive }
\end{aligned}
$$

7. The main facilities in the Mall? (Main room Facilities \& shopping center)

$$
\begin{aligned}
& 1=\text { Very Incomplete } \\
& 2=\text { Not Complete } \\
& 3=\text { Quite Complete } \\
& 4=\text { Complete } \\
& 5=\text { Very Complete }
\end{aligned}
$$

8. The existing supporting facilities in the Mall? (Supporting facilities there are places to eat drink, cinemas, game zone, stage entertainment, and other supporting facilities)

$$
\begin{aligned}
& 1=\text { Very Incomplete } \\
& 2=\text { Not Complete } \\
& 3=\text { Quite Complete } \\
& 4=\text { Complete } \\
& 5=\text { Very Complete }
\end{aligned}
$$

9. Complementary facilities in the Mall? (Complementary Facilities there are offices, toilets, parking, relaxing room, and other complementary facilities)

$$
\begin{aligned}
& 1=\text { Very Incomplete } \\
& 2=\text { Not Complete } \\
& 3=\text { Quite Complete } \\
& 4=\text { Complete } \\
& 5=\text { Very Complete }
\end{aligned}
$$

For the importance criteria (weight preference) was also assessed:

$$
\begin{aligned}
& 1=\text { Very Low } \\
& 2=\text { Low }
\end{aligned}
$$

$$
\begin{aligned}
& 3=\text { Quite } \\
& 4=\text { High } \\
& 5=\text { Very High } .
\end{aligned}
$$

Preference weights for each criterion (criteria 1 until 9) obtained from the results of interviews through a questionnaire that assessed by 100 respondents. Then the weight of the value averaged was calculated based on the rules of statistics science. That's following results of 100 respondents: $\mathrm{W}=\{4,4,4,4,3,3,4,3,4\}$.

\subsection{Result of Pre-Process}

On the results of this pre-process for values process of input data that is presented in table 2, the values in table 2 was the result of questionnaire calculation of 100 respondents who have been in average value calculated and rounded up based on rules science statistics.

Table 2.Result Pre-process

Table 2. Result Pre-process
\begin{tabular}{|c|c|c|c|c|c|c|c|c|c|}
\hline $\begin{array}{c}\text { Alter- } \\
\text { native }\end{array}$ & $\mathbf{C 1}$ & $\mathbf{C} \mathbf{2}$ & $\mathbf{C}_{\mathbf{3}}$ & $\mathbf{C} \mathbf{4}$ & $\mathbf{C}_{\mathbf{5}}$ & $\mathbf{C 6}$ & $\mathbf{C} 7$ & $\mathbf{C 8}$ & $\mathbf{C} \mathbf{9}$ \\
\hline $\mathbf{A}_{\mathbf{1}}$ & 3 & 3 & 3 & 3 & 3 & 2 & 3 & 2 & 3 \\
\hline $\mathbf{A}_{\mathbf{2}}$ & 3 & 3 & 4 & 3 & 3 & 3 & 3 & 3 & 3 \\
\hline $\mathbf{A}_{\mathbf{3}}$ & 4 & 4 & 4 & 4 & 4 & 4 & 4 & 4 & 4 \\
\hline $\mathbf{A}_{\mathbf{4}}$ & 4 & 4 & 4 & 4 & 4 & 3 & 4 & 4 & 4 \\
\hline $\mathbf{A}_{\mathbf{5}}$ & 4 & 4 & 4 & 4 & 3 & 3 & 3 & 3 & 3 \\
\hline
\end{tabular}

\subsection{ELECTRE Process}

In ELECTRE process, the result that will be assimilated calculation of ELECTRE method, the following is processing of ELECTRE method:

\section{Normalizing Matrix Decision}

To normalize matrix decision that's using equation (1) thus obtained:

$$
\begin{aligned}
& r_{11}=\frac{x_{11}}{\sqrt{\sum_{i=1}^{5} x_{i 1}^{2}}}=\frac{3}{\sqrt{3^{2}+3^{2}+4^{2}+4^{2}+4^{2}}}=0,3693 \\
& r_{21}=\frac{x_{21}}{\sqrt{\sum_{i=1}^{5} x_{i 1}^{2}}}=\frac{3}{\sqrt{3^{2}+3^{2}+4^{2}+4^{2}+4^{2}}}=0,3693 \\
& r_{31}=\frac{x_{31}}{\sqrt{\sum_{i=1}^{5} x_{i 1}^{2}}}=\frac{4}{\sqrt{3^{2}+3^{2}+4^{2}+4^{2}+4^{2}}}=0,4924 \\
& r_{41}=\frac{x_{41}}{\sqrt{\sum_{i=1}^{5} x_{i 1}^{2}}}=\frac{4}{\sqrt{3^{2}+3^{2}+4^{2}+4^{2}+4^{2}}}=0,4924 \\
& r_{51}=\frac{x_{51}}{\sqrt{\sum_{i=1}^{5} x_{i 1}^{2}}}=\frac{4}{\sqrt{3^{2}+3^{2}+4^{2}+4^{2}+4^{2}}}=0,4924
\end{aligned}
$$

For the next calculation please using equation (1). The results calculations of equation (1) then the matrix obtained by normalizing in $\mathrm{R}$ that is: $\mathrm{R}$

$\left[\begin{array}{llllllllll}0,3693 & 0,3693 & 0,3511 & 0,3693 & 0,3906 & 0,2917 & 0,3906 & 0,2722 & 0,4160\end{array}\right.$ $\begin{array}{llllllllll}0,3693 & 0,3693 & 0,4682 & 0,3693 & 0,3906 & 0,4376 & 0,3906 & 0,4082 & 0,4160 \\ 0,4924 & 0,4924 & 0,4682 & 0,4924 & 0,5208 & 0,5835 & 0,5208 & 0,5443 & 0,4160\end{array}$ $=\begin{array}{llllllllll}0,4924 & 0,4924 & 0,4682 & 0,4924 & 0,5208 & 0,5835 & 0,5208 & 0,5443 & 0,4160 \\ 0,4924 & 0,4924 & 0,4682 & 0,424 & 0,5208 & 0,4376 & 0,5208 & 0,5443 & 0,5547\end{array}$ $\begin{array}{lllllllll}0,4924 & 0,4924 & 0,4682 & 0,4924 & 0,5208 & 0,4376 & 0,5208 & 0,5443 & 0,5547\end{array}$ $\begin{array}{llllllllll}0,4924 & 0,4924 & 0,4682 & 0,4924 & 0,3906 & 0,4376 & 0,3906 & 0,4082 & 0,4160\end{array}$

\section{Calculate Matrix V}

Calculation of matrix $\mathrm{V}$ using equation (2) so that retrieved:

$$
\begin{aligned}
& v_{11}=w_{1} r_{11}=(4)(0,3693)=1,4771 \\
& v_{12}=w_{2} r_{12}=(4)(0,3693)=1,4771 \\
& v_{13}=w_{3} r_{13}=(4)(0,3511)=1,4045 \\
& v_{14}=w_{4} r_{14}=(4)(0,3693)=1,4771 \\
& v_{15}=w_{5} r_{15}=(3)(0,3906)=1,1717
\end{aligned}
$$


$v_{16}=w_{6} r_{16}=(3)(0,2917)=0,8752$

$v_{17}=w_{7} r_{17}=(4)(0,3906)=1,5623$

$v_{18}=w_{8} r_{18}=(3)(0,2722)=0,8165$

$v_{19}=w_{9} r_{19}=(4)(0,4160)=1,5623$

For next calculation please using equation (2). From equation (2) calculation of obtained Matrices V that is:

$\left[\begin{array}{lllllllll}1,4771 & 1,4771 & 1,4045 & 1,4771 & 1,1717 & 0,8752 & 1,5623 & 0,8165 & 1,5623\end{array}\right]$ $\begin{array}{llllllllll}1,4771 & 1,4771 & 1,8727 & 1,4771 & 1,1717 & 1,3128 & 1,5623 & 1,2247 & 1,5623\end{array}$ $=\begin{array}{lllllllll}1,9695 & 1,9695 & 1,8727 & 1,9695 & 1,5623 & 1,7504 & 2,0830 & 1,6330 & 2,0830 \\ 1,695 & 1,9695 & 1,627 & 1,9695 & 1,5623 & 1,3128 & 2,0830 & 1,6330 & 2,0830\end{array}$ $\begin{array}{lllllllll}1,9695 & 1,9695 & 1,8727 & 1,9695 & 1,5623 & 1,3128 & 2,0830 & 1,6330 & 2,0830\end{array}$ $\begin{array}{lllllllll}1,9695 & 1,9695 & 1,8727 & 1,9695 & 1,1717 & 1,3128 & 1,5623 & 1,2247 & 1,5623\end{array}$

\section{Determine Concordance Set}

In determining and calculating corcordance set that's using equations ( 3 ) and (5), and thus obtained: $C_{12}=\{1,2,4,5,7,9\}$

$C_{12}=W_{1}+W_{2}+W_{4}+W_{5}+W_{7}+W_{9}=4+4+4+3+$ $4+4=23$

$C_{13}=\{\}$

$C_{13}=0$

$C_{14}=\{\}$

$C_{14}=0$

$C_{15}=\{5,7,9\}$

$C_{15}=W_{5}+W_{7}+W_{9}=3+4+4=11$

For next calculation please using equation (3) and (5). From results calculation of equations (3) and (5) then the obtained matrix Corcordance $(\mathrm{C})$ that is:

$$
C=\left[\begin{array}{ccccc}
- & 23 & 0 & 0 & 11 \\
33 & - & 4 & 7 & 21 \\
33 & 33 & - & 33 & 33 \\
33 & 33 & 30 & - & 33 \\
33 & 33 & 16 & 19 & -
\end{array}\right]
$$

\section{Determine Discordance Set}

To determine and calculation Discordance set, the reseracher is using equation (4) and (6), thus obtained:

$$
D_{12}=\{3,6,8\}
$$

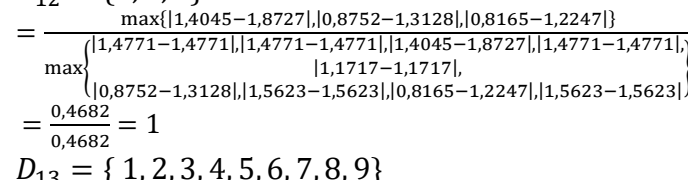

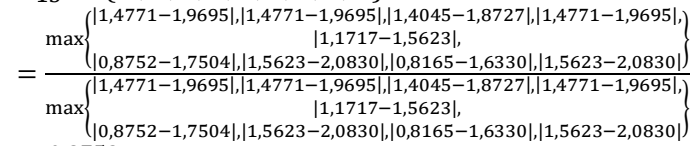

$$
=\frac{0,8752}{0,8752}=1
$$

$$
D_{14}=\{1,2,3,4,5,6,7,8,9\}
$$

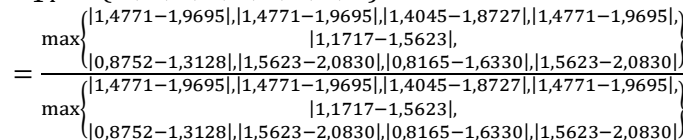

$$
=\frac{0,8156}{0,8156}=1
$$

$D_{15}=\{1,2,3,4,6,8\}$

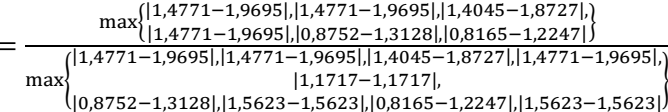

$$
\begin{aligned}
& =\frac{0,4924}{0,4924}=1
\end{aligned}
$$

For next calculation please using equation (4) and (6). From calculation equation (4) and (6) then the obtained matrices Discordance (D):

$$
D=\left[\begin{array}{ccccc}
- & 1 & 1 & 1 & 1 \\
0 & - & 1 & 1 & 1 \\
0 & 0 & - & 0 & 0 \\
0 & 0 & 1 & - & 0 \\
0 & 0 & 1 & 1 & -
\end{array}\right]
$$

\section{Find the Value of $\mathrm{c}$ and $\mathrm{d}$}

For to find the value of $\mathrm{c}$ and $\mathrm{d}$ is using calculation equation (8) and (10).

$c=$

$23+0+0+11+33+4+7+21+33+33+33+33+33+33+30+33+33+33+16+19$ $=\frac{461}{20}=23,05$

$$
d=\frac{1+1+1+1+0+1+1+1+0+0+0+0+0+0+1+0+0+0+1+1}{5(5-1)}=\frac{10}{20}=
$$

0,5

\section{Create Dominant Matrix}

It is well known the matrix $\mathrm{C}$ and $\mathrm{D}$ are as follows:

$$
C=\left[\begin{array}{ccccc}
- & 23 & 0 & 0 & 11 \\
33 & - & 4 & 7 & 21 \\
33 & 33 & - & 33 & 33 \\
33 & 33 & 30 & - & 33 \\
33 & 33 & 16 & 19 & -
\end{array}\right], \mathrm{D}=\left[\begin{array}{ccccc}
- & 1 & 1 & 1 & 1 \\
0 & - & 1 & 1 & 1 \\
0 & 0 & - & 0 & 0 \\
0 & 0 & 1 & - & 0 \\
0 & 0 & 1 & 1 & -
\end{array}\right]
$$
in matrix $E$ have a number 1 is eliminated. Thus, the best alternative is an alternative that dominated the other alternatives. To make dominant views of concordance index $C_{k l}$ exceeds the value (Threshold) $C_{k l} \geq c$ and elements of matrix concordance dominant $\mathrm{F}$ is determined as follows:

$$
F_{k l}=\left\{\begin{array}{ll}
1 & , C_{k l} \geq c \\
0 & C_{k l}<c
\end{array},\right. \text { Same applies on matrix }
$$
discordance $\mathrm{G}$ with threshold,

$$
G_{k l}= \begin{cases}1 & , d_{k l} \geq d \\ 0 & d_{k l}<d\end{cases}
$$

With using equation (9) and (11), thus the result is:

$$
\begin{aligned}
& F=\left[\begin{array}{cccccc}
- & 0 & 0 & 0 & 0 \\
1 & - & 0 & 0 & 0 \\
1 & 1 & - & 1 & 1 \\
1 & 1 & 1 & - & 1 \\
1 & 1 & 0 & 0 & -
\end{array}\right] \\
& {\left[\begin{array}{cccccc}
- & 1 & 1 & 1 & 1 \\
0 & - & 1 & 1 & 1 \\
0 & 0 & - & 0 & 0 \\
0 & 0 & 1 & - & 0 \\
0 & 0 & 1 & 1 & -
\end{array}\right] }
\end{aligned}
$$

\section{Elimination of Less Favourable Alternative}

Matrix E is generated using equation (12), its mining matrix $\mathrm{E}$, which every element is multiplication between the elements of matrix $F$ with elements of matrix $\mathrm{G}$ (Matrix $\mathrm{E}$ is a term product between element matrices $\mathrm{F}$ and element matrices $\mathrm{G}$ selected by the inventor of the ELECTRE method) By using the equation (12) so then obtained:

$\begin{aligned} \mathrm{F} & =\left[\begin{array}{ccccc}- & f_{12} & f_{13} & f_{14} & f_{15} \\ f_{21} & - & f_{23} & f_{24} & f_{25} \\ f_{31} & f_{32} & - & f_{34} & f_{35} \\ f_{41} & f_{42} & f_{43} & - & f_{45} \\ f_{51} & f_{52} & f_{53} & f_{54} & -\end{array}\right]=\left[\begin{array}{ccccc}- & 0 & 0 & 0 & 0 \\ 1 & - & 0 & 0 & 0 \\ 1 & 1 & - & 1 & 1 \\ 1 & 1 & 1 & - & 1 \\ 1 & 1 & 0 & 0 & -\end{array}\right] \\ \mathrm{G} & =\left[\begin{array}{ccccc}- & g_{12} & g_{13} & g_{14} & g_{15} \\ g_{21} & - & g_{23} & g_{24} & g_{25} \\ g_{31} & g_{32} & - & g_{34} & g_{35} \\ g_{41} & g_{42} & g_{43} & - & g_{45} \\ g_{51} & g_{52} & g_{53} & g_{54} & -\end{array}\right]=\left[\begin{array}{ccccc}- & 1 & 1 & 1 & 1 \\ 0 & - & 1 & 1 & 1 \\ 0 & 0 & - & 0 & 0 \\ 0 & 0 & 1 & - & 0 \\ 0 & 0 & 1 & 1 & -\end{array}\right]\end{aligned}$

$\mathrm{E}=\mathrm{F} * \mathrm{G}$

$\left[\begin{array}{ccccc}- & \left(e_{12}=f_{12} * g_{12}\right) & \left(e_{13}=f_{13} * g_{13}\right) & \left(e_{14}=f_{14} * g_{14}\right) & \left(e_{15}=f_{15} * g_{15}\right) \\ \left(e_{21}=f_{21} * g_{21}\right) & - & \left(e_{23}=f_{23} * g_{23}\right) & \left(e_{24}=f_{24} * g_{24}\right) & \left(e_{25}=f_{25} * g_{25}\right) \\ \left(e_{31}=f_{31} * g_{31}\right) & \left(e_{32}=f_{32} * g_{32}\right) & - & \left(e_{34}=f_{34} * g_{34}\right) & \left(e_{35}=f_{35} * g_{35}\right) \\ \left(e_{41}=f_{41} * g_{41}\right) & \left(e_{42}=f_{42} * g_{42}\right) & \left(e_{43}=f_{43} * g_{43}\right) & - & \left(e_{45}=f_{45} * g_{45}\right) \\ \left(e_{51}=f_{51} * g_{51}\right) & \left(e_{52}=f_{52} * g_{52}\right) & \left(e_{53}=f_{53} * g_{53}\right) & \left(e_{54}=f_{54} * g_{54}\right) & -\end{array}\right]$

(For multiplication of matrix $\mathrm{F}$ and $\mathrm{G}$, that is using ordinary multiplication, which is not multiplication of matrix rule, it means that multiply that is only the 
element value of matrix $\mathrm{F}$ and the element value of matrix $\mathrm{G}$ so that the obtained matrix $\mathrm{E}$ )

$$
\begin{aligned}
& \text { So the obtain, } \mathrm{E}=\left[\begin{array}{ccccc}
- & e_{12} & e_{13} & e_{14} & e_{15} \\
e_{21} & - & e_{23} & e_{24} & e_{25} \\
e_{31} & e_{32} & - & e_{34} & e_{35} \\
e_{41} & e_{42} & e_{43} & - & e_{45} \\
e_{51} & e_{52} & e_{53} & e_{54} & -
\end{array}\right] \\
& =\left[\begin{array}{ccccc}
- & 0 & 0 & 0 & 0 \\
0 & - & 0 & 0 & 0 \\
0 & 0 & - & 0 & 0 \\
0 & 0 & 1 & - & 0 \\
0 & 0 & 0 & 0 & -
\end{array}\right] \begin{array}{c}
\mathrm{A}_{1} \\
\mathrm{~A}_{2} \\
\mathrm{~A}_{3}
\end{array} \mathrm{~A}_{4} \\
& \mathrm{~A}_{5}
\end{aligned}
$$

From the results of calculation above, obtained the best is $A_{4}$ or the best is Mega Mall, because if $E_{k l}=$ 1 indicates that the alternative $A_{k}$ is a selected alternative.

\subsection{Design of Application System}

The result of making GUI based application system that can be seen in figure (3), figure (3) is result of application design without user guidelines, while for figure (4) is result of train user. In this user train the input data used is limited to 5 data, the reason is because the coding is made only up to 5 data.

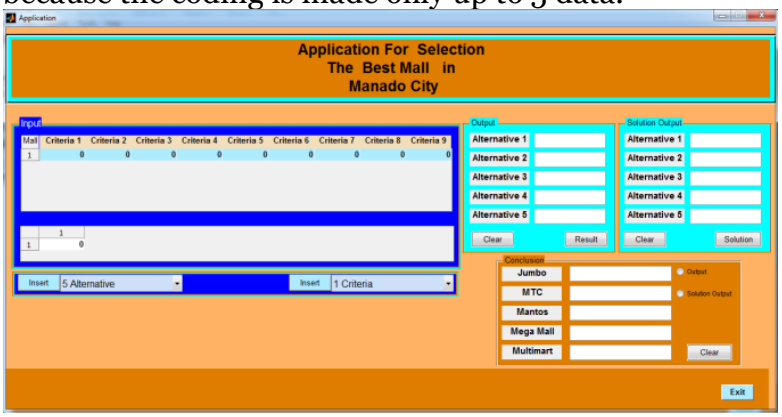

Figure 3. Application Without User Guidelines

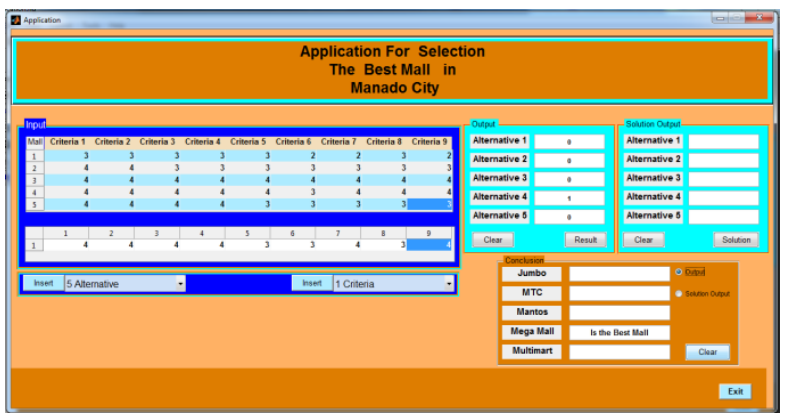

Figure 4. Application Train User

From train user application (after running) the result of GUI based application calculation is same with manual calculation result that yield result that Mega Mall is the best mall in Manado city.

\section{CONCLUSION}

1. Based on ELECTRE methods the people will know the best mall in Manado is Mega Mall.

2. This research has resulted in a recommendation for selecting the best mall in Manado by using the ELECTRE methods. ELECTRE method in this system can organize the process of elimination and generate alternatives to dominate other alternatives in recommending selection the best mall in Manado with criteria of comfort, cleanliness, location layout, hospitality, beauty, prices of basic commodities, main facilities, complementary facilities and supporting facilities so as to help the peoples in decides which mall it is best to select. This processing system generates output in the form of recommendations for selection the best mall in Manado city. On the recommendation of the best ranking then Mega Mall is the best mall in Manado.

3. In designing a GUI-based application system, the most important thing in this creation is: There must be an input value (it is a alternative table and criteria and a table preference weight), there should be an output display (if not output display will not generate rankings and conclusions) there is the execution button (because if there is no execution button then the application can not to run), and also most importantly that must create the coding in accordance with the programming language that can be read by MATLAB.

\section{REFERENCES}

[1] Marlinda, L. 2016. Sistem Pendukung Keputusan Pemilihan Tempat Wisata Yogyakarta Menggunakan Metode Elimination Et Choix Traduisant La Realita (ELECTRE). Prosiding Seminar Nasional Sains dan Teknologi; Jakarta, 8 November, 2016. Fakultas Teknik Universitas Muhammadiyah Jakarta, pp. 1-7.

[2] Marlina, E. 2008. Guide Design Of Commercial Buildings. Andi Publisher, Yogyakarta.

[3] Badan Pusat Statistik Kota Manado. 2017. Populasi Kota Manado. https://manadokota.bps.go.id/statictable/2017/0 8/18/199/jumlah- pendudukkota-manadomenurut-kecamatan-dan-jenis-kelamin-20112016.html. [5 December 2017].

[4] Kusrini. 2007. Konsep dan Aplikasi Sistem Pendukung Keputusan. Andi, Yogyakarta.

[5] Janko, W., and E. Bernoider. 2005. Multi Criteria Decision Making An Application Study of ELECTRE \& TOPSIS. Graha Ilmu, Yogyakarta.

[6] Kusumadewi, S. 2006. Fuzzy Multy Attribute Decision Making (FUZZY MADM). Graha Ilmu, Yogyakarta.

[7] Fauzi, W. 2016. Sistem Pendukung Keputusan Penerima Bantuan Dana Rutilahu dengan Menggunakan Metode ELECTRE. Prosiding Seminar Nasional Teknologi Informasi dan Komunikasi; Yogyakarta, 18-19 Maret, 2016. Hlm 432-439.

[8] Suryaningtias, P. Y. 2015. Dinamic Sistem Developmnet Method. http://yoga-pratamas.wixsite.com/yps-crypt/singlepost/2015/02/27/DYNAMIC-SYSTEMDEPELOPMENTMETHOD-DSDM. [30 January 2018]. 
Kenedi Binowo(binowoenedi@gmail.com)

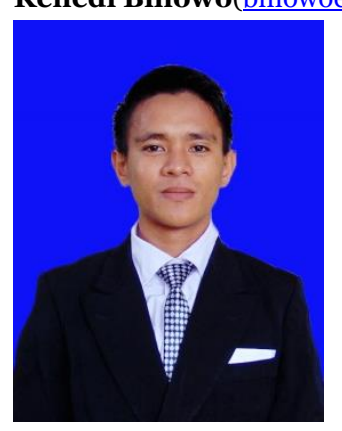

born in Bulude, Talaud, North Sulawesi, Indonesia. He still studied bachelor degree in departement Mathematics and Natural Sciences of Sam Ratulangi University of Manado. In year 2018 was the last year he studied. This journal is the result of his published research.

\section{Altien J. Rindengan (altien@unsrat.ac.id)}

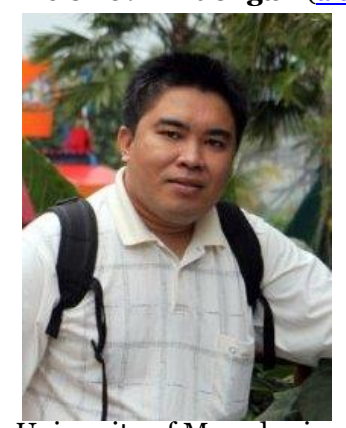

In 1999, completed bachelor degree in Mathematics Department, Faculty of Mathematics and Natural Sciences, Bogor Agriculture University. Master of computer science is obtained from the Department of Computer Science, Bogor Agriculture University, in 2012 Being a lecturer in the Department of Mathematics, Faculty of Mathematics and

Natural Sciences, Sam Ratulangi University of Manado since 2001. The focus of the researches is operational research, decision support system, fuzzy system and image proceesing

Benny Pinontoan (bpinonto@yahoo.com) born in Bitung,

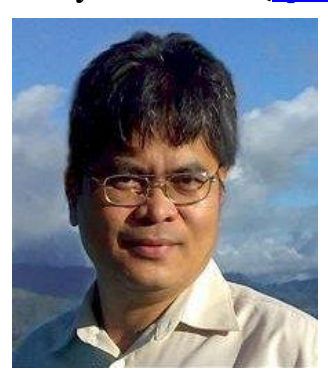

North Sulawesi, Indonesia, and lives in Manado. Completed his Bachelor degree in Technische Informatica at Faculteit Informatica Techinische Universiteit Eindhoven, The Netherlands in 1993. In 2002 he completed his Doctoral degree in Mathematics at the School of Mathematics and Statistics, Carleton University, Ottawa, Canada. In 1995 he was appointed Lecturer at Sam Ratulangi University (UNSRAT) and since 1 March 2006 became Professor of Mathematics at Faculty of Mathematics and Natural Sciences, UNSRAT. 